\title{
Contrary Things
}

m 


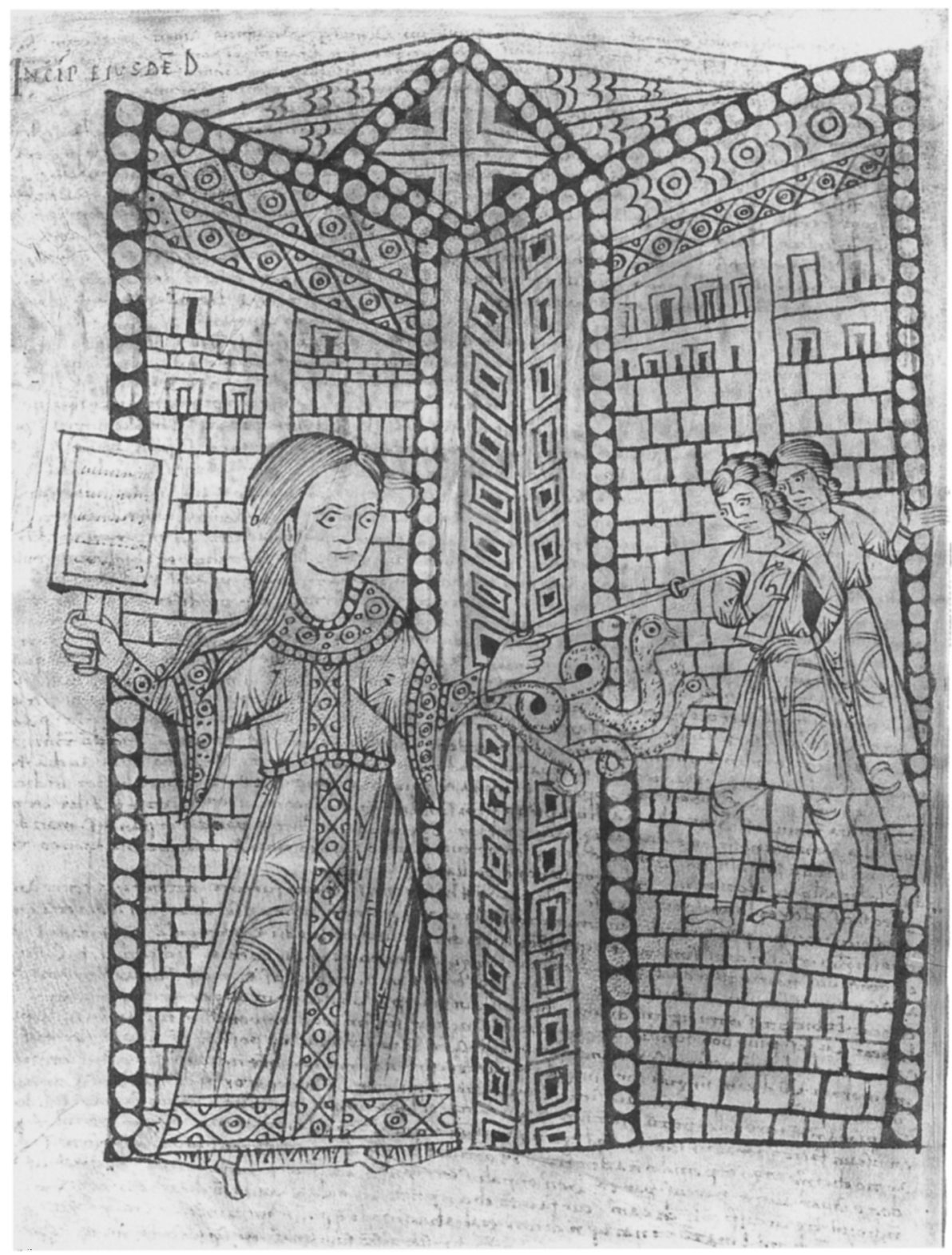




\section{Figurae}

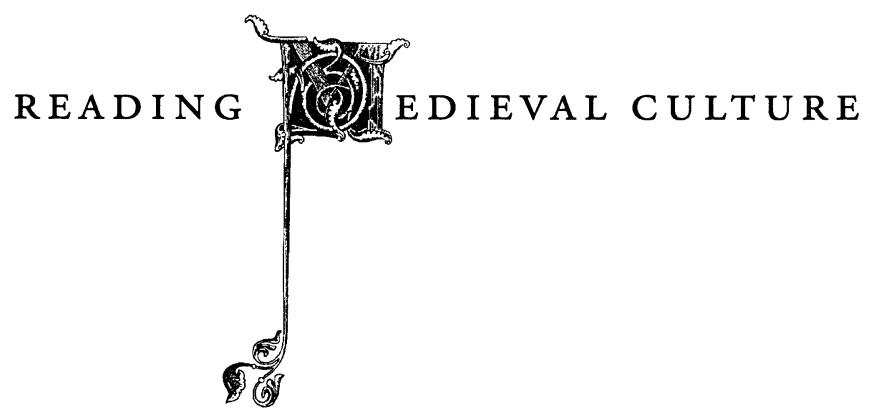

ADVISORY BOARD

Daniel Boyarin, Kevin Brownlee,

Marina Scordilis Brownlee, Jacqueline Cerquiglini-Toulet,

Hans Ulrich Gumbrecht, Rachel Jacoff,

Sarah Kay, Jan-Dirk Müller, Stephen G. Nichols,

Jeffrey Schnapp, Karla Taylor, David Wallace,

Rainer Warning, Michel Zink 



\title{
Contrary Things Exegesis, Dialectic, and the Poetics of Didacticism
}

\author{
Catherine Brown
}

Stanford University Press, Stanford, California 1998 


\section{Stanford University Press}

Stanford, California

(๑) 1998 by the Board of Trustees of the

Leland Stanford Junior University

Printed in the United States of America CIP data appear at the end of the book

Frontispiece: Dialectic and her students. Paris, Bibliothèque Nationale,

MS. Lat. $7900 \mathrm{~A}$ fol. 132v. Courtesy of the Bibliothèque Nationale. 
$\overbrace{\text { o my teachers }}$ 
